\title{
E-Government Analysis: Sultanate of Oman Case
}

\author{
Muatasim Al Salmi, Norlena Hasnan \\ School of Technology, Management and Logistics (STML), Universiti Utara Malaysia (UUM), 06010 UUM Sintok, \\ Kedah Darul Aman, Malaysia \\ Email: alsalmi.m@gmail.com
}

Received 4 January 2016; accepted 26 February 2016; published 1 March 2016

\begin{abstract}
In the current century, e-government transformation is considered as one of the biggest challenges among and within the IT-related sector from the scale and complexity perspective. Having the main objective as of adapting an existing e-government system and methodology in order to obtain new computing requirements based on the concept of citizens' new service. Thus, increase the features of service level, quality and maintaining a high policies and rules consistency. Moreover, mission criticality and time of services, information sharing and interoperability, efficiency and productivity along with the reduction of operation expenses are all considered as priorities in this transformation project (Raymond, 2007) [1]. Such a transformation is considered crucial for the service concept as it is changing rapidly; the roadmap coherence in e-government transformation is critical (Raymond, 2007) [1]. However, there is a big aspect regarding the e-Government progress by citizens due to many aspects like: Citizens-Centricity, Facilitating Condition, Effort expectancy and Performance Expectancy. Hence, there is a need to further study in order to be able to obtain better understanding of the complete picture and to have a balanced view and concepts all under one e-Government umbrella. This paper will review and analyze through a quantitative approach in Sultanate of Oman case study. This study targeted citizens in the country to check their intention to use e-Government in Oman (e-Oman). After reviewing and discussing questionnaire outputs using SPSS program, the writer listed some recommendations and conclusion of the study and the nature of them they will be categorized upon to their point of view.
\end{abstract}

\section{Keywords}

E-Government, ICT, IT, G2C, G2G, G2B, G2E, E-Oman, SPSS, IEV

\section{Introduction}

Electronic Government or in short e-Government can be defined as set of processes and government supporting and interaction systems which allow and activate citizen interaction to access to the available offered services. The extra-ordinary speed of development of ICT and great efficient and business effectiveness exhibited a strong impact in variety of day to day work and interaction between citizens, companies and economic activities. However, considering technology as a way to reduce cost and increase efficiency is not a good practice since it 
should interact and respond to client's needs (Deloitte Research, 2000) [2]. Gene, Bruce and Karin (2005, p.1) [3] stated that "The role of government has changed from leading innovation to regulating corporations that often have better equipment and more technical expertise. The Internet and related technologies have contributed to globalization by increasing both the amount of information present in the environment and the speed of information flow". This paper will review and analyze through a quantitative approach in Sultanate of Oman case study. This study targeted citizens in the country to check their intention to use e-Government in Oman (e-Oman). After reviewing and discussing questionnaire outputs using SPSS program, the writer will list some recommendations and conclusion of the study and the nature of them they will be categorized upon to their point of view.

\section{Elements of E-Government}

Some features should be determined and considered in order to properly review e-government like.

\subsection{Citizens-Centricity}

Gilmore and D'Souza (2006) [4] illustrated that it is an essential aspect to focus about the citizen in governments prospective and customer in companies prospective as the main factor while presenting a service style or changing the service approach. Hence, e-government should be presented as citizen-centricity where it basically represent the difference between the delivered services against the desired one. Moreover, it would evaluate the current service delivery in terms of meeting citizen's expectation and needs by the following attributes:

- Service design coverage against user requirements

- User interfaces languages of use against available most common local used languages

- New services style and approach against conventional services offered earlier

- The reduction of citizens visits to higher level offices for completing desired services

- Governmental employees knowledge and familiarity with the services packaged and delivery for different user groups or individuals

Lack of citizen-centricity in e-government implementation is one of the main e-government implementation challenges in developing countries. In light of this challenge, lack of citizen's participation in e-government is expected. The e-government strategy should announce and state that a successful e-government implementation needs different stakeholder's effective participation including citizens, Gunter (2006, p. 365) [5] argued that e-government "does not just depend on computer power, but also on the willingness of people to adopt it as a normal form of interface in respect of public services".

Therefore, Chan et al. (2010) [6], Vencatachellum \& Pudaruth (2010) [7], Abdulwahab \& Dahalin (2011) [8], Keramati \& Chelbi (2011) [9], Lessa et al. (2011) [10], Alzahrani \& Goodwin (2012) [11] adopted different empirical study in order to have a system facilitating e-government as more of citizen-centricity and to influence citizens and their intentions to use as the main goal. As per these recent empirical studies, it was shown that the facilitating conditions along with effort expectancy and performance expectancy has a significant impact as control factors that influences directly citizens' intention to use and it will keep e-government upon to citizens' desire and requirements. Citizens engagement is illustrated as a way of improving citizens' trust in governments and from it the government-citizens relationship to be more citizen-centricity system (Bonsón et al., 2012) [12].

\subsection{Facilitating Conditions}

Venkatesh et al. (2003)[13] defines facilitating conditions as the degree that individuals believe that organizational and technical infrastructure exists to support the system and it represents the existence resource factors one's perception like, money, time and technology factors that would facilitate or at least inhibit the latter from being utilized. Al-Zahrani (2011) [14] insisted that facilitating conditions part of the e-government adoption have a significant effect on consumers' intentions to use and it is considered as an important barrier and a significant control factor as well. There are two main dimensions included in facilitating conditions aspect which are:

- Resource factors, such as, time and money

- Technology factors, like: knowledge and country infrastructure.

Indeed, the absence of such facilities in both dimensions would affect the intention to use by citizens and lead to impede adoption of the approach. Al-Zahrani (2011) [14] further illustrated that facilitating conditions con- 
tains two main elements which are:

- Technology support, the perception about defining the resources needed in order to use e-government services, such as, PCs and Internet services,

- Government support, the perceptions about defining the efforts from government that prompt and motivate various issues and aspects related to e-government services.

Government and technology support reflects the citizens' beliefs about government role in facilitating Internet usage along with turning the project of e-government into reality. The study seeks mainly to investigate citizens' viewpoints and feedback about this role. Al-Shafi (2009) [15] argued that since e-government service is considered relatively new technology, citizens' perceptions and viewpoints about their government's role are considerably important for the project's adoption process. The more the government is perceived in playing an effective and active role in supporting e-government project as of technology or normal governmental support, the more individual citizen will be willing to use the service which will increase the intention to use.

Researchers in the field of technology studies (e.g. Moore and Benbasat, 1991; Taylor and Todd, 1995; Venkatesh et al., 2003) [13] [16]-[18] found that facilitating conditions construct has a valid positive effect on e-government project and especially the innovation use and it is found that it can be considered as a significant technology use predictor. Al-Azri, Al-Salti and Al-Karaghouli (2010) [19] conducted a qualitative research by conducting many interviews in Sultanate of Oman. Most of the interviewees believed that senior top governmental management support and commitment are imperative to provide and allocate sufficient resources and funds as well as discourage resistance and increase efficiency.

In this study, facilitating conditions was measured by taking the perception of being able to assess required resources and to obtain some knowledge and the necessary support required to use services of e-government.

\subsection{Effort Expectancy}

Venkatesh et al. (2003) [13] defines effort expectancy as the ease degree associated with the system use. Citizens usually expect some amount of effort from government in modifications and implementation of infrastructure and systems. Whereas, these visible efforts would significantly enhance the intention to use and improve their acceptance of the new approach. Indeed, this acceptance will be correlated to the trust and positive relation with the government. Barua (2012) [20] argued that it has a positive impact on the intention to use by different users from citizens or governmental employees towards the e-governance application system use. Barua (2012) [20] argued that this construct would have a significant effect especially in determining information technology user acceptance.

\subsection{Performance Expectancy}

Venkatesh et al. (2003) [13] defines performance expectancy as "the degree to which individuals believe that using a system will help them improve their job performance" and upon to Al-Shafi (2009) [15] it basically contains five different variables which are:

- Performance expectancy: citizens expectation of the system's performance against the required and the desired service applied

- Extrinsic motivation: citizens may influenced by external factors like government-citizens relationship

- Job-fit: attach the specific task and service to the most suitable system

- Relative advantage: citizens usually compare the new proposed service style against the traditional one. Upon to the correlated answer, citizen's intention will be effected

- Outcome expectations: the expectation from citizens regarding any new service approach and style is have easier, better, faster and smoother flow without putting more effort.

In this study, performance expectancy is measured by taking the perceptions of using e-government services in benefits prospective such as saving of money, time and effort along with facilitating communication between citizens and government, improving the government services quality (Al Awadhi and Morris, 2009: Al-Shafi et al., 2009) [15] [21]. Al-Shafi et al. (2009) [15] argued that performance expectancy was found to be a very strong intention to use predictor of IT.

\section{Research Methodology}

The probability sampling is the sampling applied in this research; mainly the data collection procedure will be 
by sending SMSs to a random sample of local citizens aged from 18 to 60 years which makes the filter only a demographic filter without any limitations. The researcher requires 500 respondents in order to generalize the outcome result in Oman. Therefore, the agreement with the mediator organization was to send 10,000 random SMSs upon to the attached demographic filter and the target is to get a minimum of 500 answers for the questionnaire.

\section{Data Collection}

The target population for this study is citizens in Sultanate of Oman. The unit of this study consists of citizens in business sectors, employees in government sectors, citizens without work. In Sultanate of Oman there are 42 governments and governmental agencies, a population of 3,992 million citizens upon to the last conducted national count in 2014. Where 56.6\% are Local citizens and 43.3\% expats (NCSI, 2014) [22]. Roscoe (1975) [23] took $10 \%$ as rule of thumb while choosing a sample of big group. Rescoe's decision will give an error of $3 \%$ to $4 \%$ and it is not worthy to compromise in power, time and money in order to reduce the error to $1 \%$ or $2 \%$ (Hill, 1998) [24].

The main telecommunication services provider in Oman are Omantel and Ooredoo. The researcher agreed with them through a mediator organization that have the approval and capability to send bulk categorized massages (SMS) through mobiles. The data collection procedure will be by sending SMSs to a random sample of local citizens aged from 18 to 60 years which makes the filter only a demographic filter. The researcher requires 500 respondents in order to generalize the outcome result in Oman. Therefore, the agreement with the mediator organization was to send 10,000 random SMSs upon to the attached demographic filter and the target is to get a minimum of 500 answers for the questionnaire. This method of data collection is called Push SMS application system where Naqvi, AlShihi and Ali (2011) [25] stated that a Push SMS application system is basically whereby a message is been sent from any prospective like application, person, company or governmental agency to the users, customers or citizens. However, it is considered as a one way communication method where the receiver is not forced to reply or answer the SMS because mostly it is used for marketing and broadcast information. In other words, it is a mobile application that would initiate a message. For instance, some public organizations have started to send bulk messages to public citizens or it may be also categorized and squeezed to be targeted to specific segments of citizens in terms of demographic, geographic... etc. this massage is for informing them about certain activities, products and events.

\section{Discussion}

As per the quantitative approach of survey, from 5000 distributed questionnaires, 1257 questionnaires were returned. Thus, the study's response rate is $25.14 \%$. However, after checking the obtained responses Out of these returned questionnaires, only 585 questionnaires were usable and applicable for analysis because the rest didn't answer all questions and they skipped some of them. So, the usable response rate is $12 \%$.

As stated earlier, the survey is not covering all citizens in Sultanate of Oman but it will cover only citizens in the ages between 18 to 60 years old. The reason behind this is that citizens younger than 18 years old don't require government services in general and as per the low in Oman they will not starting work before that. The same situation for citizens older than 60 years old because this is the retirement age in the Sultanate. Tests like Missing Data, Normality, Descriptive, Validity and Reliability were done and found suitable and matching the report concern. The framework is listed in Figure 1.

\section{Recommendations and Conclusions}

The main purpose of this study was to develop an integrated model investigating e-government services citizens' acceptance in Sultanate of Oman that would affect the government operation excellence. The first step in the study was by conducting an extensive literature review for deriving the adoption relevant factors. The research aimed to understand the current e-Government services practices, concept, categories and stages. Since the study is conducted for the empirical work in Sultanate of Oman, it was considered essential and important to gain and obtain enough knowledge about the context of the field study especially in the country for distinct cultural characteristics.

The e-government success is contingent upon citizen willingness and intention to use e-government services. Government of the country should give important consideration to develop IT projects without forgetting to 


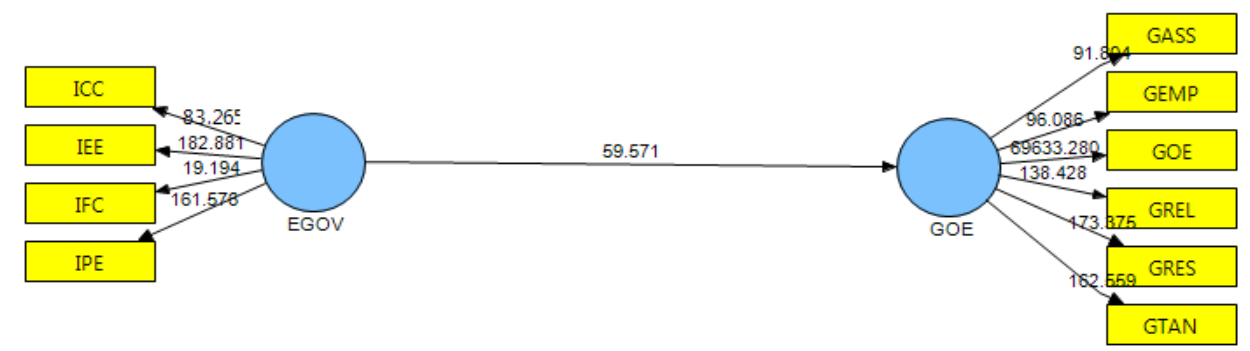

Figure 1. Study framework.

focus on citizen's viewpoints in order to transfer traditional services to online form successfully. An understanding of the citizen acceptance relevant factors in e-government can provide policy and decision makers with a set of strategic management plans in order to build and prompt greater acceptance towards these services. The research's results hold important and essential strategic suggestions for various government departments and agencies that provide e-government services in increasing the citizens' adoption rate.

In terms of e-Government, the results score the importance of citizen's trust in government for adoption. Government should give more effort on building positive government-citizen relationships as they are considered the main customers and accordingly the main factor that will affect the success or failure of the e-Government project. Hence, it is considered important and essential to have the necessary skills and expertise while conducting the project for smooth achievement of the goal. Furthermore, co-operating with competent wellknown businesses in e-services and e-government area in order to enhance government-citizens relationship and to make the project more citizen-centricity should enhance citizen trust towards government. On the other hand, citizen's effort expectancy and performance expectancy from government is effecting e-Government project in general and will decrease trust in government which would effect GOE. Government should facilitate better environment and platform for the project in order to enhance citizen's acceptance toward the project as well as achieving GOE significantly and successfully. For instance, the Internet is insignificant for developers to implement the latest advance tools, equipment and foundations with significant security standards. Government could focus to promote and educate citizens about the provided e-services by e-government technology that would provide the confidence and overcome the available barriers between individuals and the technology. Clear visions, missions and strategies for developing e-Government in the country could help in facilitating the e-Government adoption. Such initiatives could encourage citizens' intention to use e-Government as a national successful project.

\section{References}

[1] Wu, R.C.-Y. (2007) Enterprise Integration in E-Government. Emerald Group Publishing Limited, IBM Software Group, Singapore.

[2] Deloitte Research (2000) At the Dawn of E-Government: The Citizen as Customer - State Government Approaches to Customer Service, Deloitte Consulting and Deloitte \& Touche, 1-18.

[3] Brewer, G.A., Neubauer, B.J. and Geiselhart, K. (2005) Designing and Implementing Egovernment Systems: Critical Implications for Public Administration and Democracy. University of South Florida Tampa, Florida.

[4] Gilmore, A. and D’Souza, C. (2006) Service Excellence in E-Governance Issues: An Indian Case Study, JOAAG, India.

[5] Gunter, B. (2006) Advances in E-Democracy: Overview. Aslib Proceedings: New Information Perspectives, 58, $361-70$. http://dx.doi.org/10.1108/00012530610692320

[6] Chan, F.K.Y., Thong, Y.L.J., Venkatesh, V., Brown, S.A., Hu, P.J.H. and Tam, K.Y. (2010) Modelling Citizen Satisfaction with Mandatory Adoption of E-Government Technology. Journal of the Association for Information Systems, 1, 519-549,

[7] Vencatachellum, I. and Pudaruth, S. (2010) Investigating E-Government Services Uptake in Mauritius: A User’s Perspective. International Research Symposium in Service Management, Mauritius.

[8] Abdulwahab, L. and Dahalin, Z.M. (2011) A Conceptual Model of Unified Theory of Acceptance and Use of Technology (UTAUT) Modification with Management Effectiveness and Program Effectiveness in Context of Telecentre. African Scientist. 
[9] Keramati, A. and Chelbi, A. (2011) The Adoption of E-Government Services by Employees in Iran, Case Study: Rasht Municipality. Department of Business Administration and Social Sciences, Lulea University of Technology.

[10] Lessa, S.N.L. and Amoroso, D.L. (2011) Acceptance of WoredaNet E-Government Services in Ethopia: Applying the UTAUT Model. Proceedings of the Seventheenth American Conference on Information Systems, Detroit, Michigan.

[11] Alzahrani, M.E and Goodwin, R.D. (2012) Towards a UTAUT Based Model for the Study of EGovernment Citizen Acceptance in Saudi Arabia, World Academy of Science, Engineering and Technology.

[12] Bonsón, E., Torres, L., Royo, S. and Flores, F. (2012) Local E-Government 2.0: Social Media and Corporate Transparency in Municipalities, Sector Público, Spain.

[13] Venkatesh, V., Morris, M., David, G. and David, F. (2003) User Acceptance of Information Technology: Toward a Unified View. MIS Quarterly, 27, 425-478.

[14] Al-Zahrani, A.I. (2011) Web-Based E-Government Services Acceptance for G2C: A Structural Equation Modeling Approach, De Montfort University, UK.

[15] Al-Shafi, S.H. (2009) Factors Affecting E-Government Implementation and Adoption in the State of Qatar. Brunel University, London.

[16] Moore, G.C. and Benbasat, I. (1991) Development of an Instrument to Measure the Perceptions of Adopting an Information Technology Innovation. Information Systems Research, 2, 173-191. http://dx.doi.org/10.1287/isre.2.3.192

[17] Taylor, S. and Todd, P. (1995) Understanding Information Technology Usage: A Test of Competing Models. Information Systems Research, 6, 144-176. http://dx.doi.org/10.1287/isre.6.2.144

[18] Taylor, S. and Todd, P. (1995) Decomposition and Crossover Effects in the Theory of Planned Behavior: A Study of Consumer Adoption Intentions. International Journal of Research in Marketing, 12, 137-155. http://dx.doi.org/10.1016/0167-8116(94)00019-K

[19] Al-Azri, A., Al-Salti, Z. and Al-Karaghouli, W. (2010) The Successful Implementation of E-Government Transformation: A Case Study in Oman. EMCIS2010, 12-13.

[20] Barua, M. (2012) E-Governance Adoption in Government Organization of India. International Journal of Managing Public Sector Information and Communication Technologies (IJMPICT), India.

[21] Al Awadhi, S. and Morris, A. (2009) Factors Influencing the Adoption of E-government Services. Academy Publisher, Journal of Software, Kuwait University/Library \& Information Science Department, Kuwait.

[22] NCSI (2014) National Centre for Statistics and Information. http://www.ncsi.gov.om

[23] Roscoe, J.T. (1975) Fundamental Research Statistics for the Behavioral Sciences [by] John T. Roscoe. Holt, Rinehart and Winston, New York.

[24] Hill, M.C. (1998) Methods and Guidelines for Effective Model Calibration. US Geological Survey, Denver, 90.

[25] Naqvi, S.J., Al Shihi, H. and Ali, S. (2011) Mobile Services in Oman: A Feedback on SMS-Parking Service, Informing Science, SQU, Oman. 